\title{
Boston Meeting of the American Association
}

$\mathrm{T}$ HE ninety-third meeting of the American Association for the Advancement of Science was held in Boston on December 27-January 2. Harvard University and the Massachusetts Institute of Technology, with which other colleges in the metropolitan area co-operated, were sponsors and furnished rooms and other facilities for most of the sessions, which were thus admirably provided for. The Boston area is a centre of outstanding interest. Its educational and scientific features were placed at the disposal of visiting men of science and added in significant fashion to the effectiveness of the meeting.

The local committee, with Dr. A. L. Lowell, president of Harvard University as honorary chairman and Dr. K. T. Compton, president of the Massachusetts Institute of Technology as honorary vice-chairman, provided well for the needs of the occasion. Despite the violent attack of historical New England winter on the first day, the programme was carried through successfully, due to the work of Prof. S. C. Prescott, chairman, and his associates. The attendance numbered more than 3,200 scientific workers and the programme included 1,475 papers. All fifteen sections of the Association were active and 34 of its affiliated societies held meetings. In addition, the Academy Conference brought together official representatives of 19 State academies of science on Wednesday. These affiliated academies are active agencies in the advancement of science in their particular regions and meet annually with the Association to discuss problems involved in their co-operation and to agree on plans for future work.

Most secretaries of sections and of affiliated societies remained for a study of organisation problems on the day following adjournment.

A noteworthy event, not on the official programme, was the dinner given to Dr. J. McKeen Cattell. On December 27, before the opening session, one hundred and thirty representative members and friends gathered to show their appreciation and pay respect to him for distinguished services to the Association. The feature of the programme was an address by Prof. John Dewey on "The Supreme Intellectual Obligation".

The first formal session on December 27 was opened with the president, Prof. H. N. Russell, in the chair. After customary addresses of welcome and response, the retiring president, Dr. John J. Abel, of Johns Hopkins University School of Medicine, addressed the audience on "Poisons and Disease". He discussed the chemical nature of disease as demonstrated adequately for certain diseases such as lock-jaw and diphtheria and strongly suggested in many other cases, hence the current trend towards the view that all diseases are due to poisons. As he said, "Nature has not affixed a poison label to any particular substance or class of substances ; the pharmacist does that." Dr. Abel further pointed out that many materials in the human body, and even the vitamins, though necessary and helpful in limited quantities, become poisons in larger doses. "I incline to the belief," he stated, "that no living cell exists whose contents or metabolites are not toxic to some other living cell."

The second Hector Maiben lecture, an endowed annual event, was given by Prof. W. M. Davis on the topic, "The Faith of Reverent Science". In this he set forth his concept of the views of reverent science and the hope of the future in the growing co-operation between thinkers in the fields of science and religion.

On December 28 the general session was in charge of Sigma Xi, the Society for the Promotion of Research. The speaker, Prof. Henry E. Sigerist, addressed the Society and guests on the topic, "The Foundations of Human Anatomy in the Renaissance":

The Sedgwick memorial lecture, which was established by the Biological Department of the Massachusetts Institute of Technology, was given on December 29 by Dr. Henry Fairfield Osborn. The magnificently illustrated lecture was an effective presentation of the subject "Aristogenesis, the Creative Principle in the Origin of Species".

On the same day, the Chemistry section and the North-Fastern Section of the American Chemical Society meeting jointly were addressed by Prof. Lafayette B. Mendel on "The Challenge of Nutrition to the Chemist".

The general session on Agriculture and Engineering on December 29, arranged with co-operation also of the section on Social and Economic Sciences, portrayed vividly the trend of the times. The Secretary of Agriculture, the Hon. Henry Agard Wallace, spoke on "What can Engineering do for Agriculture ?" His address was an appeal to engineers to forsake laissez-faire philosophy and to join in building up a co-operative State. He charged scientific workers with failure to weigh social consequences and challenged the widespread self-centred attitude of the past. "To-day when the industrial nations of the world have skimmed most of the cream off the backward nations and the backward classes and when there are no longer any challenging geographical frontiers to be conquered, it becomes apparent", he said, "that we must learn to co-operate with each other instead of joining together in the exploitation of someone else."

On December 30 the American Academy of Arts and Sciences, meeting jointly with the Association, presented the Rumford medal for distinguished research in physics to Prof. Harlow Shapley, director of Harvard College Observatory and Paine professor of astronomy at Harvard, after which he addressed the meeting on "The Anatomy of a Disordered Universe". He elaborated the view that while the universe as a whole may be expanding, that part of it closest to man shows the opposite tendency.

A series of well-organised joint sessions and symposia formed an important feature of the pro. gramme. Indeed the entire three-day programme of the section of Medical Sciences consisted of a series of such features. Of particular general interest were the symposia on "The Chemical Revolution" by the sections of Chemistry and Social Sciences, on "National Economic Policy in its Relation to Our International Policy" by the section of Social and Economic Sciences, on "New England Dialect and Colonial Culture", by the section of Historical and Philological Sciences, on the "Development and Growth of the Nervous System", by the section of Zoological Sciences, on the "Positron" by the section of Physics, on "Engineering and the Farm Problem" by the sections of Engineering, Agriculture, and Social and Economic Sciences. 
Four of the prominent affiliated societies, namely, the American Society of Naturalists, the American Society of Zoologists, the Botanical Society of America, and the Genetics Society of America, held a joint session on December 30 on the theme "Biology and Society". Prof. W. M. Wheeler spoke on "Animal Societies", Prof. E. A. Hooton on "Primitive Human Societies", and Prof. F. H. Hankins on "Development of Modern Social Organization". 'The American Society of Parasitologists and the section of Medical Sciences in joint session presented a programme on the "Typhus Group of Organisms", with demonstrations which aroused great interest. Other joint sessions of affiliated societies on plant physiology, ecology, entomology, phytopathology, parasitology and dental research would merit special comment if space permitted.

On December 30 the American Society of Naturalists celebrated its semi-centennial anniversary. Prof. S. H. Gage was honorary chairman. After dinner the anniversary address was delivered by Prof. E. G. Conklin on "Fifty Years of the American Society of Naturalists". Prof. B. E. Livingston read his presidential address on "Environments".

The addresses of the retiring vice-presidents, given at various times, included the following: Mathematics, Prof. H. H. Mitchell, "Linear Groups and Finite Geometries"; Physics, Dr. D. L. Webster, "Current Progress in X-Ray Physics"; Chemistry, Dr. Frank C. Whitmore, "Some General Aspects of the Polymerization and Depolymerization of Olefins"'; Astronomy, Dr. P. W. Merrill, "Invisible Star Light" ; Geology and Geography, Dr. William H. Hobbs, "The Glaciers of Mountains and Continents"; Zoology, Prof. A. S. Pearse, "Ecological Segregation"'; Botany, Dr. H. L. Shantz, "Botanical Research"; Anthropology, Dr. C. H. Danforth, "Genetics and Physical Anthropology"; Psychology, Dr. Walter S. Hunter, "The Stimulus Control of Behavior during and after Learning"'; Education, Prof. Stuart A. Courtis, "Differential Testing as a Method of Psychological Analysis"; Social and Economic Sciences, Prof. William F. Ogburn, "Recent Trends in Social Sciences"; Historical and Philological Sciences, Dr. Waldo G. Leland, "Recent Trends in the Humanities"; Engineering, Prof. Dugald C. Jackson, "The Origins of Engineering"; Medical Sciences, Dr. C. R. Stockard, "Internal Secretions and Genetic Quality in Structural Development"; Agriculture, Prof. Joseph H. Gourley, "Plant Anatomy as a Tool in Agricultural Research".

The Science Exhibition, now a regular feature of the annual meeting, was, despite adverse economic conditions, the most successful yet undertaken. Colleges, private and Government research laboratories presented new and important work, both in pure and applied science; commercial exhibits of apparatus and products were extensive; among the displays of publications in science those of university presses were conspicuous, and the exhibits made by associations of teachers in biology, physics and mathematics attracted marked attention.

The Committee on the Place of Science in Educa. tion had arranged a special conference in which relations between teaching and the advancement of science were discussed from diverse points, and the results of new experiments in laboratories, science clubs and State academies reported.

The American Association prize of 1,000 dollars was awarded by the Committee on Awards to Dr. Reuben L. Kahn, bacteriologist of the University of Michigan, for his paper on "Tissue Reactions in Immunity: the Specific Reacting Capacities of Different Tissues of an Immunized Animal". By a method of measuring the degree of immunity acquired by different tissues, as shown by the author's investigations, warfare against germ diseases may be more successfully conducted.

The British Association was represented at the meeting by Prof. Arthur E. Kennelly of Harvard and Prof. F. E. Lloyd of MeGill ; the French Association by Prof. W. M. Davis of Harvard, and the Bohemian Royal Society by Prof. Henry B. Ward of Illinois. Special delegates were also appointed by many American institutions.

The following officers were elected for the year 1934: President, E. L. Thorndike of Columbia University; Council Members, F. K. Richtmyer of Cornell University, J. C. Merriam of Carnegie Institution; Members of the Executive Committee, K. T. Compton of the Massachusetts Institute of Technology, E. G. Conklin of Princeton University; Trustee of Science Service for three years, to April 1937: J. McKeen Cattell; Vice-Presidents of the Sections, 1934: R. D. Carmichael, mathematics ; H. G. Gale, physies; Joel H. Hildebrand, chemistry ; Frederick Slocum, astronomy ; Jas. B. Macelwane, geology and geography; George L. Streeter, zoological sciences; B. O. Dodge, botanical sciences; M. J. Herskovitz, anthropology ; John E. Anderson, psychology; Carl Snyden, social and economic sciences; Solon J. Buck, historical and philological sciences; C. E. Skinner, engineering; Cyrus C. Sturgis, medical sciences ; J. G. Lipman, agriculture ; Guy T. Buswell, education; Secretary of Section I, John A. McGeoch.

\section{Invention and Legislation}

$\mathrm{A}^{\mathrm{T}}$ the sixth annual general meeting of the Television Society held at University College, London, on March 14, an address was given by the president, Sir Ambrose Fleming, on "Invention in Relation to National Welfare and its Legislative Control". Sir Ambrose referred to progress in television as an instance of one of the most interesting of the technical applications of science. It fulfils the same function with regard to the eye that radiotelephony does for the ear. It annihilates distance and enables us to see living and moving objects which would otherwise be invisible. In short, it enables us to be in two places at the same time.
We are then led to consider the question how such an achievement can be made to contribute to national welfare, apart from its interest as a mere scientific novelty or amusement.

The great advances made in the use of short electric waves and closer scanning, and in photoelectric cells and cathode ray tubes, have made corresponding advances possible in television, and we can now transmit images of pictures, diagrams, or living persons and reproduce them on screens $3-4 \mathrm{ft}$. square, visible to large audiences at the receiving stations. We have in this ability a valuable means of education. Lectures and school lessons can be 